\title{
Use of a Dot Immunobinding Assay for Rapid Detection of Strawberry Pseudo Mild Yellow Edge Virus
}

\author{
Nobuyuki Yoshikawa*, Pissawan PoolPol* and Tadao INOUYE* \\ Key words : strawberry pseudo mild yellow edge virus, dot immunobinding assay, rapid detec- \\ tion.
}

Yoshikawa and Inouye" have recently characterized strawberry pseudo mild yellow edge virus (SPMYEV) as a new member of the carlavirus group. The virus was successfully purified from Alpine strawberry (Fragaria vesca L. var. semperflorens (Duch.) Ser.) and used for antiserum production in a rabbit. The titer of the antiserum obtained was $1 / 2048$ as determined by microprecipitin test ${ }^{11}$. Further tests by an indirect ELISA method ${ }^{2)}$ showed that SPMYEV could be detected at a minimum concentration of $50 \mathrm{ng} / \mathrm{ml}$ for purified virus and a dilution of $1: 1,000$ for infected leaf extract (Fig. 1). In the present paper, we have tested the applicability of a dot immunobinding assay (DIBA), recently reported by Hibi and Saito ${ }^{3)}$, for rapid, simple diagnosis of SPMYEV in strawberry.

Antiserum against SPMYEV was cross-absorbed with freeze-dried leaf sap of healthy Alpine strawberry prepared by the same procedure used for virus purification ${ }^{1}$. The absorption was performed as previously described ${ }^{3}$. The anti-rabbit IgG goat IgG conjugated with alkaline phosphatase (Tago, Inc., Burligame, Ca., U. S. A., 21,700 units $/ \mathrm{ml}$ ) diluted 1:3,000 was used as the second antibody for detection of virus
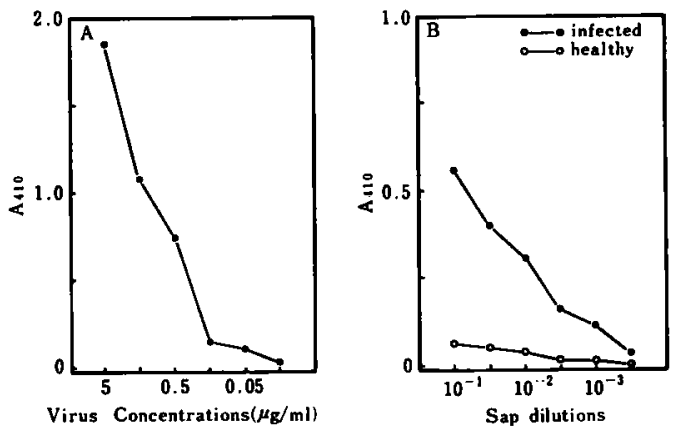

Fig. 1. Indirect ELISA of purified SPMYEV (A) and crude sap from infected and healthy strawberry leaves (B). Indirect ELISA described by Koenig ${ }^{2)}$ was used. The dilutions of virusspecific IgG and anti-rabbit IgG goat IgG were $1: 1,000$ and $1: 2,000$, respectively. Crude sap was extracted using $0.1 \mathrm{M}$ borate buffer, $\mathrm{pH} 8.2$ containing $0.01 \mathrm{M}$ EDTA and $2 \%$ PVP.

* College of Agriculture, University of Osaka Prefecture, Sakai 591, Japan 大阪府立大学農学部 Present address of N. Yoshikawa: Faculty of Agriculture, Iwate University, Morioka 020, Japan 岩手大学脤学部

Present address of P. Poolpol : Central Laboratory and Greenhouse Complex, Kasetsart University, Nakornpathom, Thailand 73140

1) Yoshikawa, N. and Inouye, T. (1986). Ann. Phytopath. Soc. Japan $52: 643-652$. 2) Koenig, R. (1981). J. gen. Virol. $55: 53$. 3) Hibi, T. and Saito, Y. (1985). J. gen. Virol $66: 1191$. 
specific IgG. All antisera used were diluted with antibody buffer $(0.02 \mathrm{M}$ Tris- $\mathrm{HCl}, 0.5$ $\mathrm{M} \mathrm{NaCl} \mathrm{pH} 7.5$ containing $0.05 \%$ Tween $20,2 \%$ polyvinylpyrrolidone (PVP) and 0.2 \%o bovine serum albumin).

To test for efficacy of DIBA in detecting SPMYEV, sap from virus-infected and healthy plants was prepared by grinding $1 \mathrm{~g}$ of leaf tissue in $10 \mathrm{ml}$ of borate buffer" The crude sap was centrifuged to remove plant debris and the supernatant was diluted serially using TBS-Tween $(0.02 \mathrm{M}$ Tris- $\mathrm{HCl}, 0.5 \mathrm{M} \mathrm{NaCl} \mathrm{pH} 7.5$ containing $0.05 \%$ Tween 20). Purified virus diluted in the same buffer to several concentrations was used for sensitivity testing. The reagents for the DIBA test were the same as in the previous report ${ }^{3)}$ except for the color development solution. The substrate used in all experiments contained $6 \mathrm{mg} / \mathrm{ml}$ of Fast Red TR salt (Sigma) in $0.2 \mathrm{M}$ Tris-HCl buffer $\mathrm{pH} 8.2^{4}$. Just prior to use, this solution was mixed $1: 1$ with $0.1 \%$ naphthol AS-MX phosphate (Sigma) in the same Tris buffer. The DIBA procedures were performed as follows: a nitrocellulose sheet (pore size $0.45 \mu \mathrm{m}$, Bio-Rad) was cut into strips, and the sites to spot samples on a strip were marked $1 \mathrm{~cm}$ apart by a pencil. The strip was immersed in TBS for $5 \mathrm{~min}$ and placed on filter paper to dry. With a micropipette, two $\mu \mathrm{l}$ of each antigen solution was spotted onto a site on the strip, and allowed at least $10 \mathrm{~min}$ to dry thoroughly. The strip was then put into blocking agent (antibody buffer containing $2 \%$ bovine serum albumin) for $20 \mathrm{~min}$ and blotted briefly on filter paper. The strip was placed onto a glassplate, covered with sufficient amount of cross-absorbed antiserum (diluted $1: 8,000$ ) and incubated in a moist chamber for $20 \mathrm{~min}$. The strip was then washed with antibody buffer by shaking at a frequency of 60 excursions/ $\min$ for $15 \mathrm{~min}$ and blotted on filter paper. The strip was again transferred onto the glass plate, covered with the second antibody and incubated as above for $20 \mathrm{~min}$. After washing in TBS-Tween with shaking for $15 \mathrm{~min}$ and blotting briefly on filter paper, the strip, placed on the glass plate, was then flooded with the substrate freshly prepared as mentioned above, and incubated in a moist chamber. Positive reactions producing a bright pink color could be visualized within $30 \mathrm{~min}$. The reaction was terminated by rinsing the strip in distilled water.

As shown in Fig. 2, by visual evaluation, SPMYEV was detected at a minimum concentration of $5-50 \mathrm{pg}$ of purified virus and a sap dilution $1: 5,000$. Sap from healthy plant used as a control gave no positive reaction

Virus concentrations(ng)

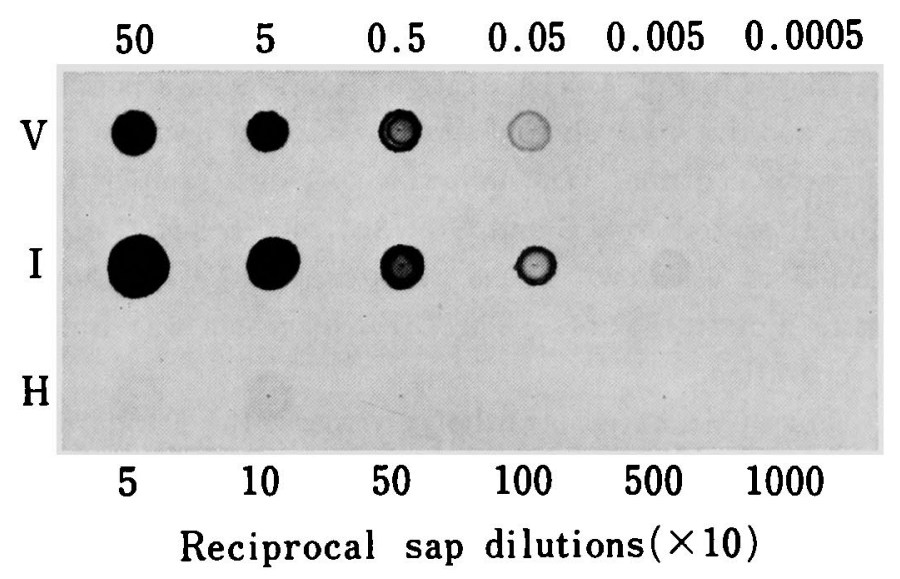

Fig. 2. The sensitivity test of DIBA with purified SPMYEV (V) and crude sap from infected (I) and healthy (H) strawberry leaves.

4) Banttari, E. E. and Goodwin, P. H. (1985). Plant Disease $69: 202$. 
even when used at a dilution of $1: 50$. When the concentration of first antibody (virusspecific antiserum) was varied from 1:2,000 to $1: 8,000$, color intensity of positive reactions were nearly the same, but concentrated antisera produced an intense background color. A $1: 8,000$ antiserum dilution was therefore used in all subsequent experiments.

The next test was done for optimizing the extraction buffer in order to detect SPMYEV in strawberry. We evaluated five extraction buffers, i. e., i) $0.1 \mathrm{M}$ borate buffer $\mathrm{pH} 8.2$ containing $0.01 \mathrm{M}$ ethylenediamine tetraacetate (EDTA) and 2\% PVP, ii) $0.05 \mathrm{M}$ sodium carbonate $\mathrm{pH} 9.6$, iii) TBS-Tween, iv) antibody buffer, and $V$ ) distilled water. The results are shown in Fig. 3. Only borate buffer gave a good positive reaction with a bright pink color.

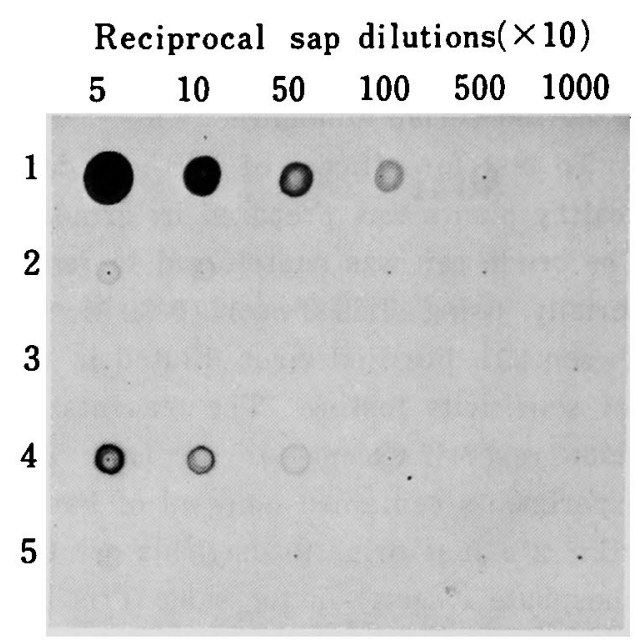

Fig. 3. The effect of extraction buffers on the sensitivity of DIBA. 1) $0.1 \mathrm{M}$ borate buffer $\mathrm{pH} 8.2$ containing $0.01 \mathrm{M}$ EDTA, 2\% PVP, 2) $0.05 \mathrm{M}$ sodium carbonate buffer $\mathrm{pH} 9.6,3)$ TBS-Tween, 4) antibody buffer, 5) distilled water.

Although positive reactions were also ob-

tained with antibody buffer, sensitivity was very low compared with borate buffer. Borate buffer was therefore used as an extraction buffer.

The practical diagnosis of SPMYEV from strawberry was successively performed. Sample preparation was done by crushing completely a leaf piece $\left(4 \mathrm{~mm}^{2}\right)$ cut from the midrib area in a drop of $10-20 \mu 1$ borate buffer on a parafilm sheet. Two $\mu 1$ of crude sap was directly spotted on the nitrocellulose strip at the marked sites. In this way, spotting of about 50 samples could be finished within an hr. Virus-infected and healthy leaves were used as controls. An example of SPMYEV diagnosis by the DIBA method is shown in Fig. 4. The first row (A-I) shows positive reactions of infected strawberry leaf positive controls and 7 th row showed negative reactions of healthy strawberry leaf negative controls. The following unknown samples were judged to be positive : $\mathrm{B}, \mathrm{C}, \mathrm{D}$ and $\mathrm{H}$ of 2 nd row, $\mathrm{C}$ and $\mathrm{G}$ of 3 rd row, $\mathrm{B}$ and $\mathrm{C}$ of 4 th row, $\mathrm{B}, \mathrm{C}$, and $\mathrm{H}$ of 5 th row, and $\mathrm{B}$ of 6 th row. These results agreed with those obtained by leaf-grafting on $F$. vesca indicator plants. The DIBA diagnosis was finished within $4 \mathrm{hr}$, including sample preparation.

For aphid-borne strawberry viruses, the standard assay has been done by a leafgrafting on specific strawberry indicator plants ${ }^{5,6}$. Symptom diagnosis by this method requires at least a month after grafting. The DIBA method described in this paper was found to be very rapid, simple and sensitive for detection of SPMYEV in strawberry. This method is considered to be potentially very useful for diagnosis of other

5) Frazier, N. W. (1974). Plant Dis. Reptr. $58: 28$. 6) Converse, R. H. (1979). Plant Dis. Reptr. $63: 848$. 
strawberry virus diseases as specific antisera against those viruses are developed.

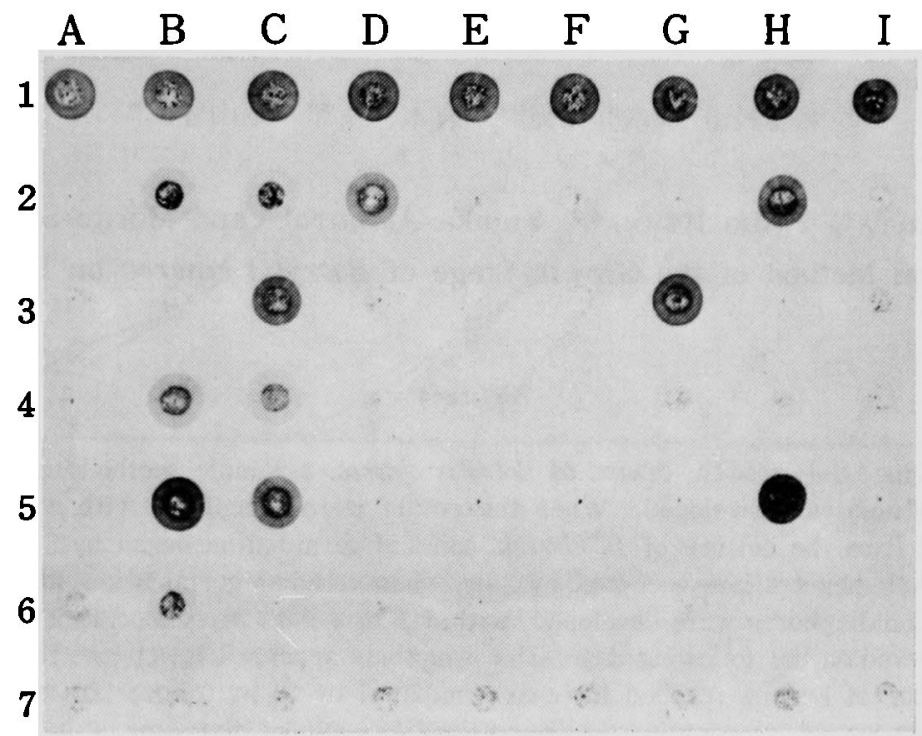

Fig. 4. An example of SPMYEV detection from plant sap by the DIBA method. Sample preparation was done by crushing a leaf piece on a parafilm sheet described in the text. The dilutions of virus-specific IgG and antirabbit IgG goat $\lg G$ were $1: 8,000$ and $1: 3,000$, respectively. The first row (A-I) was infected strawberry positivec ontrols and 7 th row was healthy strawberry negative controls. The 2 nd to 6 th rows were unknown samples.

We thank Drs. T. Osaki and S. T. Ohki, College of Agriculture, University of Osaka Prefecture, for useful discussion. We are also indebted to Dr. R. H. Converse. United States Department of Agriculture, Oregon State University, for his critical reading of the manuscript.

\section{和 文 摘 要}

吉川信幸・Pissawan Poolpol ・ 井上柋男 : Dot immunobinding assay による Strawberry pseudo mild yellow edge virus $の$ 検出

Dot immunobinding assay (DIBA) によるイチゴからの Strawberry pseudo mild yellow edge virus (SPMYEV) の検出条件を検剖した。SPMYEV 特異的抗体 $(8,000$ 倍希釈)を一次抗体に，アルカリフォスフ アターゼ標識抗ウサギ IgG-ヤギ IgG（Tago 社製）を二次抗体として本法の検出限界を調べたところ，精 製ウイルスでは 50-5 pg, 粗汁液では5,000倍希釈まで検出が可能であった。イチゴ葉の磨碎使用する縓衝液 には $0.1 \mathrm{M}$ ホウ酸, $\mathrm{pH} 8.2$ (0.01 M EDTA，2\% PVP を含む) が最適であった。本法は結果の判定まで 3 時間程度しか要せず，しかも検出感度が高いことから，イチゴからの SPMYEV の検出に非常に有効な方法 であることが明らかになった。

(Received March 5, 1986) 